\title{
Leadership Level and Motivation of School Headship to Treatment of Teacher's Performance at High School 2 Seunagan
}

\author{
Musliadi $^{1}$, Cut Zahri Harun ${ }^{2}$ and Yusrizal $^{3}$ \\ ${ }^{1}$ Guru SMA Negeri 1 Seunagan, Indonesia \\ ${ }^{2}$ Prodi Magister Administrasi Pendidikan Universitas Syiah Kuala, Banda Aceh, Indonesia \\ \{1adimusliadi300@gmail.com\}
}

\begin{abstract}
The research in this thesis is motivated by the leadership style of the principal. The most important element in realizing education progress in the school environment is the principal. Where the success of the school in improving the quality of education is the success of the principal in playing its role in the managerial side. A successful school principal is if he is able to understand the existence of the school as a complex and unique organization and is able to carry out the role of the principal as a person who is given the responsibility to lead the school. Furthermore, a very important element in education is the teacher. Teachers are a key element in the education system, especially in schools. So that with the leadership style of the teacher's principal, supervision and performance of a teacher will be a professional educator. The formulation of the problem in this thesis is how are the leadership style and motivation of the principal towards improving teacher performance at SMA Negeri 2 Seunagan. Research method: this research uses descriptive-analytic method with qualitative approach. The population in this study were all teachers at SMA Negeri 2 Seunagan. Data collection methods are in the form of conservation, questionnaire. Data analysis used is descriptive analysis. From the results of this study, the authors concluded that: (1) In his leadership the principal of SMA Negeri 2 Seunagan conducted several strategies to improve teacher performance, namely EDS (School Self Evaluation), Planning for teacher quality improvement in order to improve teacher performance. (2) The principal runs his function as a top manager, organizer, administrator, and supervisor so that he has carried out his duties well, giving encouragement to the teachers to actively work according to certain procedures and methods, so that the work runs smoothly and reaches the target. (3) A teacher does not only deliver the subject matter, but the teacher also motivates the students. At SMA Negeri 2 Seunagan, the teachers have provided motivation to the students, both those who have no achievements and those who have achieved achievements.
\end{abstract}

Keywords: Leadership Style, Motivation, and Teacher Performance

\section{Introduction}

The quality of education in a school organization is influenced by the quality of leadership of the principal. One of the strengths in the management of school organizations and the role to be responsible for dealing with change is the Principal Leadership, as a leader the Principal is required to be able to initiate new thinking in the process of interaction in the school 
environment, in carrying out the process to achieve school goals in accordance with the demands of the times

A leader who is less instrumental in creating harmonious communication and providing employee coaching will cause a low level of employee performance. The role of an important leader to achieve desired organizational goals, including organizations in a school institution such as SMA Negeri 2 Seunagan, which has a lot of direct contact with services to academic civitas, namely students, teachers, employees, and other communities. fast, precise, easy and cheap.

State High School 2 Seunagan is one of the government agencies serving under the Education Office that aims to educate the nation intensively and continuously is an absolute thing that must be continued and programmed As one of the schools in Nagan Raya District, as a government institution carrying out its tasks, of course, the size of the teacher's performance can be seen from the results (output) and the ability to carry out their main tasks and functions

Leadership style is a behavior norm used by someone when a person tries to influence the behavior of others. Leadership style is a consistent pattern of behavior that is shown by the leader and is known by others when the leader tries to influence the activities of others.

Motivation is a potential force that exists in a human being, which can be developed by itself, or developed by a number of external forces. With the motivation of teachers, they will be able to form high morale. The ability of teachers based on motivation will encourage them to show strong behavior so that they can be directed to achieve certain goals. This orientation certainly leads to the role of the teacher who is required to act professionally.

Work motivation can be defined as influential conditions that generate, direct and maintain behaviors related to the work environment. The work environment in question is school, school as an organization in which there are a number of people who work together in order to achieve goals. As a result of one motivational action is the achievement of work performance of the organization as a whole.

Thus the success of the teacher in carrying out the task because of encouragement/motivation as a sign of what has been done by the teacher has touched the needs. Teachers who are motivated in work will lead to job satisfaction because the needs of teachers who are fulfilled encourage to improve their performance.

The importance of teaching performance in improving optimal student learning achievement is one of the external forces that can be used by a teacher to carry out his influence in teaching. Increased work must be accompanied by high motivation. Working without motivation is certainly very boring because there is no driving force. Motivation is giving or driving that creates excitement for someone to work together, integrated and all efforts to achieve satisfaction.

In building good teacher performance and quality it is necessary to have leadership techniques in achieving these goals. As an effort to maintain harmonization, the welfare of teachers and adjust to the situation and conditions of subordinates. Based on some of the descriptions above, it can be said that the principal's leadership style and teacher's work motivation are important factors in influencing teacher performance.

The right leadership style desired by subordinates is behavior that is seen as a source of satisfaction, both for present interests and needs and for a better and brighter future. In relation to the behavior of these leaders, there are two things that are usually done to subordinates, namely the behavior of directing and supporting behavior. Both norms of behavior are placed on two separate and distinct axes so that it can be known that various leadership styles are in accordance with situations and conditions that can affect the performance of the teacher. Based on observations while the researchers saw there were several problems that occurred in SMA 
Negeri 2 Seunagan namely, there were still some Teachers who refused orders and policies from superiors, it was seen by some teachers who preferred to be outdoors during teaching hours and the imbalance between regulations written with implementation in the field. Based on this condition, this study entitled "The Influence of Leadership Style and Motivation of Principals on Teacher Performance at State 2 Public High School".

\subsection{Problem Formulation}

Based on the description above, the problem in the research which is the formulation is whether the leadership style and motivation of the principal affect the performance of the teacher at SMA Negeri 2 Seunagan?

\section{Literature Review}

Leadership is defined in individual traits, habits, ways of influencing others, interaction, position in organization and perception of legitimate influence and moving the behavior of others and doing.

According to Wahjosumidjo [1] Leadership is translated into terms of traits, personal behavior, influence on others, patterns of interaction, cooperation relationships between roles, the position of one administrative office, and perception of others about legitimacy influence".

Leadership style contains understanding as a manifestation of the behavior of a leader, which concerns his ability to lead. Leadership style basically is a manifestation of the behavior of a leader, which concerns his ability to lead. The embodiment usually forms a certain pattern or form. In carrying out his leadership a leader cannot be separated from the existence of a style or often referred to as a leadership style.

According to Obiwuru, Okwu, Akpa, \& Nwankwere [2] states that the concept and definition of leadership and style may differ from one person, or situation, to the other. The word "leadership" has been used in various aspects of human resources such as politics, businesses, academics, social works, etc. Previous views about leadership show it as personal ability.

From the statement above it can be concluded that the concept and definition of leadership and style may be different for each person. The word "leadership" has been used in various aspects of human business such as politics, business, academia, social work, etc. so leadership shows it as personal ability. The essence of leadership is following (followership), the willingness of others or subordinates to follow the leader's wishes, that is what causes a person to become a leader. In other words, the leader will not be formed if there are no subordinates.

Pahrudin [3] revealed that performance is the result achieved by a person after carrying out his duties in accordance with the responsibilities in order to achieve the stated goals. whereas according to Zahraini [4] states that performance is a form of personal creativity carried out based on their duties and functions as workers.

The Principal's leadership greatly colored the working conditions. Policies, social influences with teachers and students and also their actions in making various policies, these conditions also have an impact on the performance of teachers. Thus there is a positive relationship between the principal's leadership and the performance of elementary school teachers. This can be said also the better the leadership of the principal increases the teacher's performance.

Ismail [5] suggests that: performance is the result achieved by a person according to the size that applies to the work in question, meaning that if a person's behavior gives results that are in accordance with the standards or criteria that are standardized by the organization, then the performance is good and if otherwise means poor performance, or in other words standard 
setting is needed to know whether employee performance is in line with the expected goals, while also seeing the magnitude of deviations by comparing actual work results with expected results.

The approach used in this study is a quantitative approach. According to Sugiyono [6], quantitative approaches are research data on quantitative approaches in the form of numbers and analysis using statistics". The reason researchers use a quantitative approach is that researchers intend to eliminate subjectivity in research. This study uses the assessment instrument survey method. This method is used to determine the influence/relationship between independent variables and dependent variables.

\section{Result and Discussion}

The principal of SMA Negeri 2 Seunagan has carried out his duties well, giving encouragement to the teachers to actively work according to certain procedures and methods, so that the work runs smoothly and reaches the target.

To be able to carry out their duties properly, a school principal must have skills not only in the field of administration, but also must have the ability to lead, organize, be able to provide motivation and encouragement to teachers, education personnel, and students to study harder so that students can get good performance and the success of the school will also increase quickly.

In order for these things to happen, a school principal must have three types of skills. First, organizational skills. A tangible manifestation of this skill is how the school principal is able to formulate the school's vision and mission which is further elaborated in an educational program whose implementation is structured in such a way in an organizational framework organized in a neat and systematic education program. Both human skills, namely the skills to cooperate, motivate and lead. And third, technical skills, namely skills in using knowledge, methods, techniques, and equipment to complete certain tasks.

As for the things done by the principal in improving teacher performance at SMA Negeri 2 Seunagan as follows:

1. Self Evaluation for Improving Teacher Performance in Seunagan Senior High School 2

State High School 2 Seunagan has conducted School Self Evaluation (EDS). The implementation of EDS every year, which is carried out by the School Development Team (TPS) consisting of school principals, representatives of teachers, representatives of school committees, representatives of parents, and supervisors. The existence of School Self Evaluation (EDS) makes State High School 2 Seunagan have internal tools or instruments that can be used to evaluate their performance, can find out where their level of achievement is seen from Minimum Waiter Standards and National Education Standards, can know their strengths and weaknesses for certain and can know with certainty and can prioritize improving the quality of teachers in the State High School 2 Seunagan.

2. The Principal Plans to Improve the Quality of Teachers of State High School 2 Seunagan to improve teacher performance

The strategy of the headmaster of planning to improve the quality of teachers of State High School 2 Seunagan is carried out by making plans for improving the quality of teachers by multiplying it to the school's vision, mission, and planned goals. Planning is carried out by involving all school academics including involving teachers in determining the program or future plans. The planning carried out by the principal has also been based on needs analysis and job analysis.

3. Principals Implement Teacher Quality Improvement in order to improve teacher performance 
The strategy of the principal in carrying out the improvement of the quality of teachers of State Seunagan Secondary School 2 was carried out by involving teachers in scientific forums (seminars, training courses, workshops, workshops and courses), further studies, revitalization of MGMP, welfare benefits, provision of supporting facilities such as provision of internet facilities to access new information, purchase new books that support teacher performance and include teachers in professional certificate programs.

\section{Principals Implement Monitoring and Evaluation}

The principal's strategy to carry out monitoring and evaluation of the improvement of the quality of teachers of State High School 2 Seunagan is carried out by evaluating the development of teacher quality. The evaluation carried out is by supervising the education of the teachers. There are three supervision techniques used: class visiting techniques; private talks and group discussions. While the approach used is direct (directive) and indirect (nondirective). The objectives and aspects evaluated are teacher attendance (attendance), teacher performance, student achievement and development, class notes, in this case, are daily, weekly, monthly to semester tests, syllabus and teacher's RPP. In addition to using education supervision, the school head also conducts assessments using an assessment format that has been standardized by the government known as the Performance Appraisal List (DP3)

The constraints faced by the principal to improve the quality of education are that there are still teachers who are low in awareness of the quality of teachers, the lack of competent teachers and the lack of teachers as needed. Whereas the solution taken by the Principal of State High School 2 Seunagan in overcoming the obstacles to improving teacher quality is by continuously communicating and campaigning on the culture of education quality for teachers who are still low in awareness and applying for teachers through the Seunagan District Education Office, as well as by appointing honor teacher to overcome teacher shortages.

\section{Conclusion}

In accordance with the research that has been done and the discussion about the leadership of the principal in improving teacher performance, the authors draw the following conclusions:

1. In his leadership, the principal of SMA Negeri 2 Seunagan conducted several strategies to improve teacher performance, namely Eds (School Self Evaluation), Planning for teacher quality improvement in order to improve teacher performance

2. Principals carry out their functions as top managers, organizers, administrators, and supervisors so that they have carried out their duties well, which is to encourage teachers to actively work according to certain procedures and methods so that the work runs smoothly and reaches the target.

3. A teacher does not only deliver the subject matter, but the teacher also motivates the students At Seunagan State High School 2, the teachers have given motivation to the students, both those who have no achievements and those who have achieved

\section{REFERENCES}

[1] Wahjosumidjo, Kepemimpinan kepala sekolah. Tinjauan teoretik dan permasalahannya. Jakarta: PT. RadjaGrafindo Persada, 2011.

[2] T. C. Obiwuru, A. T. Okwu, V. O. Akpa, and I. A. Nwankwere, "Effects of leadership style on organizational performance: A survey of selected small scale enterprises in Ikosi-Ketu council development area of Lagos State, Nigeria," Aust. J. Bus. Manag. 
Res., vol. 1, no. 7, pp. 100-111, 2011.

[3] Pahrudin, "Peningkatan kinerja dan pengembangan profesionalitas guru sebagai upaya peningkata mutu pendidikan di Indonesia," in Prosiding Seminar Nasional Pendidikan Ekonomi \& Bisnis, 2015.

[4] Zahraini, "Kinerja dosen dalam meningkatkan kemampuan akademik (hard skill) dan penguasaan keterampilan (soft skill) pada mahasiswa PKK FKIP Unsyiah," J. Ilm. Didakt., vol. XIV, no. 2, pp. 350-367, 2014.

[5] T. Ismail, "Kepemimpinan, kompensasi, motivasi kerja, dan kinerja guru SD negeri," $J$. Adm. Pendidik., vol. XXIV, no. 1, pp. 60-69, 2017.

[6] S. Sugiyono, Metode penelitian kuantitatif, kualitatif, dan R\&D. Bandung: Alfabeta, 2014. 